\title{
Jerusalem and the border, evolutive aspects
}

\author{
IreneSalenson*
}

\begin{abstract}
A bstract. What meaning does the term border take on referring to a city? The city of Jerusalem is an interesting case study because with it the whole polysemy of the word border shows up, on every geographical scale. Since the start of the AIAqsa Intifada in 2000, support for the idea of a physical barrier between Israel and the Palestinian territories has grown tremendously among Israelis. On Jerusalem's external boundary, this barrier takes the form of an eight-metershigh-wall. The Israeli government does not admit that the barrier's sole purpose was the prevention of terrorist incursions. A policy of ethnic separation was clearly intended, the argument being that co-existence between Israelis and Palestinians had been a failure. How did the Holy city reach this pessimistic point, considering that the idea of an international city was proposed twice in the first half of the twentieth century, when its inhabitants had already suffered a separation between 1948 and 1967, and when a peace process had been initiated in 1994? Will this barrier become the new border between Israel and Palestine, between West and East Jerusalem?

Keywords: Jerusalem, frontier, separation fence, municipal territory, international city.
\end{abstract}

Resumen. ¿Qué significa el término frontera con respecto a una ciudad? La ciudad de Jerusalén es un caso de estudio interesante debido a que en ella aparece la polisemia total de la palabra frontera en cada uno de los niveles geográficos. Desde inicios de la Intifada Al-Aqsa en 2000 , ha cobrado una gran fuerza entre los palestinos la idea de una barrera física entre Israel y los territorios palestinos. En los límites externos de Jerusalén, esta barrera toma la forma de un muro de ocho metros. Por su parte el gobierno israelí no acepta que el único propósito de la barrera fuese prevenir la incursión de terroristas. Es evidente que el motivo era la política de separación étnica, bajo el argumento del fracaso de la convivencia entre israelíes y palestinos. ¿Cómo fue que la Ciudad Santa llegó hasta este punto tan pesimista, cuando la idea de una ciudad internacional fue propuesta en dos ocasiones durante la primera mitad del siglo $\mathrm{xx}$ y siendo que sus habitantes ya habían sufrido una separación entre 1948 y 1967, y se había iniciado un proceso de paz en 1994? ¿Se convertirá esta barrera en la nueva frontera entre Israel y Palestina, entre Jerusalén del Este y del Oeste?

Palabras clave: Jerusalén, frontera, cerco de separación, territorio municipal, ciudad internacional.

* PHD student, University La Sorbonne, Paris. E-mail: irenesalenson@yahoo.fr 


\section{Introduction}

In this paper I will explore the different meanings of the term border, by which I mean to refer to more than the simple idea of a boundary between independent states which is, of course, how border is commonly understood. What does the term mean in reference to a city? Borders can constitute an urban entity's administrative frontier, but also its internal boundaries, as with the demarcation lines found between neighborhoods or functional areas. The city of Jerusalem is an interesting case study in this respect because with it the whole polysemy of the word border shows up.

In Arabic, the word for border is hadd (plural form: hudud) and in Hebrew, the word is gvul. In the classic Ben-Yehuda Hebrew dictionary, the English translation for gvul is border; in German it is die Grenze, and in French, limite and frontière. We should note that use of the words border or boundaries in English and frontière in French is more restricted than gvul and hadd imply, as the latter also mean limit. In general, gvul in the singular can refer to the internal area included within a set of the borders (only the plural form, gvulot, immediately designates external boundaries). In the Bible, the word is sometimes used to refer to the whole promised land except for Jerusalem, Jerusalem being Israel's heart, and all the rest designated gvul, which in this context means periphery (Smotriez, 1998).

Two other notions of border also arise in the case of Jerusalem: the American idea of the frontier, in the sense of the outer edge of territories to be conquered, and the idea of frontier as a physical obstacle that separates places. In this sense, the idea of border represents the exclusion of a certain space or a population, located on the other side of the line (Newman, 1999).

In the one hundred years between 1867 and 1967, Jerusalem was transformed from a small impoverished town, onethat had remained circumscribed by its walls since antiquity, into a large metropolitan area. Until the second half of the nineteenth century, the borders of the city could be equated with those of its outlying walls. The division between urban and rural spaces was physically obvious, and had re mained stable since the Middle Ages. As a whole, the city during this 
period comprised no more than $1.5 \mathrm{~km}^{2}$. By the end of the 19th century, however, construction outside those walls constituted an audacious conquest of the surrounding area, invoking the American notion of the frontier. Today, the municipality's boundary covers $126 \mathrm{~km}^{2}$, an area populated by 680,000 inhabitants, while greater Jerusalem consists of a region of $500 \mathrm{~km}^{2}$, including Givat Zeev, Maale Adumim and, according to some definitions, Ramallah and Bethlehem. It should be noted as well that although the border between east and west Jerusalem disappeared in 1967, a new separation is being established with the construction of the Security Fence (but not between the same east and west).

\section{N ew interests in Palestine at the end of the 19th century}

The great powers of Great Britain, Russia and France developed an interest in Palestine as a result of its proximity to theSuez Canal. So it was not that Pal estine was considered intrinsical ly interesting; rather, it was its position at the crossroads between richer domains, e.g. Lebanon, Syria, and Egypt, that attracted the great powers. During this time, the pre-Zionist, followed by the Zionist, movements arose. ${ }^{1}$ Given the waves of Jewish emigration, Jerusalem's population was becoming too large to be contained comfortably within its walls. It was at the end of the nineteenth century that the first neighborhoods were built outside the walls. ${ }^{2}$ These new neighborhoods represented a kind of disruption in the urban development. We can describe the borders of this expanding city in terms of the American frontier: rural territories were conquered which had hitherto not been considered for inclusion in the urban space, as they were not protected by the encircling wall of Old Jerusalem. A process of urbanization in the modern sense was thus under way. The new neighborhoods were becoming faubourgs while the spatial organization of Arab society

\footnotetext{
${ }^{1}$ The first Zionist Congress was held in Bale, Switzerland, in 1897.

2 Mishkenot Shaananim and Migrash haRussim in 1860; Moshava Germanit in 1873.
} 
remained a largely rural collection of distinct villages attached to agricultural or pastoral territories. Throughout the process, the new Jewish neighborhoods delimited themselves with protective walls whose gates were closed at night.

By 1910, the Jewish population of Jerusalem had attained the status of majority. ${ }^{3}$

\section{Jerusalem at the start of the 20th century: A borderless international city?}

On two occasions during the first half of thelast century, thetransformation of Jerusalem into an international city formed part of a specific plan.

According to the terms of the Sykes-Picot Agreement of 1916, by which the great powers divided the Ottoman Empire amongst themselves, Jerusalem and its environs would be subject to tripartite administration by France, Great Britain and Russia. Britain, however, took control of the region for itself in 1917 and established its Palestinian mandate in 1920. The tripartite administration thus never materialized, Jerusalem having become the headquarters for British authorities alone.

On November 29, 1947, the United Nations General Assembly approved a plan to divide the region into two separate states, one Arab and theother Jewish. The plan called for borders to be drawn according to a principle of ethnic national separation. Jerusalem, however, was a more problematic case: the un resolved that "the City of Jerusalem shall be established as a corpus separatum under a special international regime and shall be administered by the United Nations". The idea of an international city arose for the second time, one that would cover a very wideperimeter in order to includethetown of Bethlehem

\footnotetext{
${ }^{3}$ In 1912, according to N eher-Bernheim R. (1997), there were 70,000 inhabitants in the city: 45,000 Jews, 12,000 Muslims, and 13,000 Christians. According to a Palestinian source (A ref AI A ref, 1961), there were 62,000 inhabitants in 1922, of whom 34,000 were Jews and 28,000 Arabs.
} 
because the great powers sought to maintain control over all of the Christian holy sites (Hirsch, and Lapidoth, 1994). Yet the un plan never came to fruition. Violent clashes between Jewish and Arab communities in Palestine grew ever more frequent. After the 1948 War between the new state of Israel and the neighboring countries, Jerusalem, rather than becoming a city un protection, was divided: Trans Jordan had sovereignty over its eastern quarters, and the new Israel over the west, a no man's land appearing in between. The border between them was never negotiated, and represented no more than an informal cease-fire zone. As to the Arab quarters that fell under Israeli control, Katamon, Talbiye, and Baka, the majority of their Arab residents had fled during the war. Israel's A bsentee Property Law of 1950 formally expropriated their homes, thelaw having declared that the State had the right to take possession of all real estate left abandoned by its owner for more than five years. This law, it is worth noting, was an inheritance from Ottoman rule, ${ }^{4}$ not a new creation of the Israeli government. The city of Jerusalem would remain divided for 20 years thereafter.

\section{7: Israel conquers East Jerusalem and expands its borders}

In June of 1967, following its victory in the Six Day War, the state of Israel took control of East Jerusalem and celebrated the reunification of the city, proclaiming Jerusalem to be its eternal capital and the old city and holy sites to be inalienable ${ }^{5}$

The Jordanian municipal council of Jerusalem was thus dissolved and, from this point on, a single municipal authority governed the holy city. The surface area of East Jerusal em under Jordanian control had been a mere $6 \mathrm{~km}^{2}$; later $64 \mathrm{~km}^{2}$ were added on, bringing the total area of Jerusalem to $108 \mathrm{~km}^{2}$. The line of municipal demarcation avoided heavily populated Palestinian towns such as Ramallah,

\footnotetext{
4 The 1880 Ottoman law of M ahlul concerning absentees' property.

${ }^{5}$ On N ovember 22, 1967, the un Security Council passed Resolution 242, which called for Israel's withdrawal from the occupied territories, including East Jerusalem.
} 
Bethlehem, and Abu Dis. For a variety of reasons, however, twentyeight Palestinian neighborhoods and villages were included within its limits. Some, such as Sheikh Jarrah, Ras el Amoud, Silwan, lay in close proximity to the old city, with which they formed an urban continuity; others -Shu'fat, Bet Hanina to the north, Abu Tor, Beit Safafa to the south- were included to ensure the control of roadways leading to Ramallah and Bethlehem.

Until 1967, Jerusalem had represented a point of impasse in geographic terms: a sort of dead-end for Israeli territory at theedge of the Latrun corridor. After 1967 and the conquest of East Jerusalem and the West Bank, however, it became the center-point of the country's map, and could no longer be considered a border town. To confirm its centrality, Jewish Israeli inhabitants were moved into East Jerusalem and areas of the West Bank.

As its first major attempt at urban planning, the new municipal government launched a campaign to redevelop the Jewish quarter of the old city, where Jews had taken shelter as of medieval times and up until the 1948 war (Sharon, et al., 1973). The neighborhood induded dozens of synagogues, many of which had been partially destroyed by the Jordanians. Its borders were a problem in themselves: the reconstructed perimeter was wider than the area of the medieval Jewish quarter and spilled over into Arab neighborhoods. ${ }^{6}$ A nother complication arose from the fact that many Jewish families, out of either religious or national conviction, had chosen to establish their homes in other parts of the medieval city. Religious groups like Ateret Cohanim and Atara Leyoshna took it as their mission to "reestablish the Jewish way of life" in the old city by buying back houses which had belonged to Jewish families at the end of the 19th century or at the start of the 20th, including those located in Muslim areas. ${ }^{7}$

\footnotetext{
${ }^{6}$ Also, in order to construct a square in front of the Wailing Wall, the Israelis proceeded to demolish several blocks of Palestinian houses in the M ughrabi quarter (Dumper, M., 1997).

${ }^{7}$ In 1936, during the Arab revolt against British rule, and again in 1948-1949, all the Jewish inhabitants of the old city had fled the Arab quarters as a result of interethnic tensions.
} 
Moreover, ten new Jewish quarters were created outside the wall of the old city, in the eastern sector of the municipal perimeter. ${ }^{8}$ The building of these neighborhoods had several aims: to unify Jerusalem under Israeli sovereignty by strengthening its Jewish identity; to establish physical control over Palestinians through the army's presence in the city; and to modify the apparent spatial distribution of each community, so that Israeli claims to territory in the Holy City could be legitimized for later negotiations over borders (Dieckhoff, 1989).

Jerusalem's borders were also extended by the designation of a greater metropolitan region. On July 30, 1980, the government declared the "Basic Law: Jerusalem, Capital of Israel", which held that the city must remain unified forever. And the national planning commission imposed the boundaries of a $500 \mathrm{~km}^{2}$ metropolitan region intended to represent a G reater Jerusalem, even though this larger perimeter had no real legal or administrative status. The greater metropolitan region was designed to bring a swathe of Jewish settlements into the orbit of Jerusalem -settlements which lay around Palestinian villages, no longer within the municipal boundaries but outside, within the West Bank (Legrain, J.F., 1996). It delineated an almost complete circle, the avowed aim of which was to defend the capital city. Their inhabitants had the right to bear arms. In this context, thenew boundary resembled more of a frontier, in which the emphasis was on conquering virgin space or desert (cf. the settlement of Maale Adumim, in the desert of Judea, to the east of Jerusalem). By this process, the government was both following and lending support to a spontaneous movement of settlers financed by private initiatives, both individual and collective, which had begun in the late $1970 s^{9}$ (Newman, 1985). By the start of the following decade, the State itself became involved in this

\footnotetext{
${ }^{8}$ A tarot, N eve Yacov, Pisgat Zeev, Ramot Allon, Ramat Schlomo, Givat Tserfatit, Talpiot, Givat Hamatos, Gilo and Har Homa.

9 The first constructions by the Gush Emunim movement, created in 1973, were considered illegal until the conservative Likud Party came to power in 1977. The Begin government, in 1978-1979, granted Gush Emunim the right to settle three areas permanently.
} 
movement through the construction of new towns. The growth of these settlements has continued down to the present day. ${ }^{10}$

The expansion of Jerusalem has also included areas to the west, in pre-1967 Israeli territory. In 1988, Jerusalem's mayor, Teddy Kollek, announced his intention to integrate the city's western suburbs into the municipality. His stated motivations were, first, to strengthen the Jewish demographic majority, which was losing ground as a result of the higher birth rate in Arab communities and, second, to bolster the socio-economic status of Jerusalem's population, which was among the lowest in the nation. In 1993, the project received partial approval, and $15 \mathrm{~km}^{2}$ of territory were annexed to the municipality. Today, a new project foresees the annexation of an additional $40 \mathrm{~km}^{2}$ west of Jerusalem.

What has been the position of the international community regarding developments? At the end of 2002, the United Nations General Assembly passed a new resolution condemning the Basic Law of Jerusalem and rejecting Israel's annexation of East Jerusalem. Thus, from the point of view of international jurisdiction, the post1967 Israeli quarters in East Jerusalem are illegal, irregardless of their location within the limits of municipal Jerusalem.

\section{The borders and the peace process, 1994-2000}

Before the Camp David conference of 2000 , the peace process did not focus on the question of Jerusalem. In fact, it was considered too sensitive to be addressed until late in the negotiations. ${ }^{11}$ In the Oslo Accords of September 1993, the Israeli government agreed to withdraw from part of the occupied territories. But the Israeli prime minister, Itzhak Rabin, did not include the settlements of Greater Jerusalem in this withdrawal plan, citing their strategic importance (Encel, 1997). The prime ministers that followed, Benjamin

\footnotetext{
${ }^{10}$ According to a report of February 17, 2004, by the NGO Shalom Arshav, 102 outposts were built on the West Bank between September 2000 and February 2004. ${ }^{11}$ The sensitive issues defined in Oslo were: Jerusalem, water, refugees, borders, and security forces.
} 
Netanyahu, Ehud Barak and A riel Sharon, all stated repeatedly that they opposed the creation of new settlements but not the enlarge ment of those al ready in place, which they believed should be allowed to follow a pattern of natural growth, as the expression went. According to a report by the NGo Shalom Arshav, more than 5,000 Israeli housing units were under construction in the occupied territories in 2002. The majority of these buildings pertained to settlements lying close to the Green Line ${ }^{12}$ or inside Greater Jerusalem. So the appropriation of land, and the shrinking of the frontier (in the American sense of the word), was still occurring in Jerusalem, especially in areas that lay outside its municipal boundaries.

From the Pal estinian point of view, Jerusalem's borders took on a new meaning after the Oslo Accords. Despite the suspension of the Intifada and the promise of a peace agreement, Palestinian citizens had become less free than before as a result of the frequent cordon operations in the autonomous zone. Access to Jerusalem had be came less easy for the inhabitants of the West Bank, the central role of the city thus being diminished while that of Ramallah increased in importance.

At the Camp David conference in July 2000, US President Bill Clinton proposed a new solution for dealing with the Jerusalem problem. It took the form of a simple slogan: "Jewish (Israeli) sovereignty in the Jewish quarters, Arab (Palestinian) sovereignty in the Arab quarters". If this idea had been put into practice, the Jewish quarters of East Jerusalem would have become Israeli enclaves inside Palestinian territory, and the Palestinian territory would have been divided up.

And what of the old city, with its complex mixture of Jewish and A rab neighborhoods? On which sideof theborder would itlie? Would it be part of an Israeli or Palestinian municipality? Disagreement over the old city was a key reason for the failure of negotiations at Camp David. The Palestinians agreed to leave the Jewish quarter and

\footnotetext{
12 The 1949 ceasefire line. Much of the international community regards the Green Line as the border between the State of Israel and the Palestinian territories on the West Bank.
} 
the Wailing Wall under Israeli sovereignty insisted on control over the Arab neighborhoods (both Muslim and Christian). The Israelis, for their part, refused to giveup any part of theold city to the sovereignty of a future Palestinian state. They proposed instead that Palestinians enjoy relative autonomy in the A rab quarters and completeautonomy in the faubourgs. During the Taba Talks in January 2001, one could note some progress on that issue: Israel accepted Palestinian sovereignty over the Arab neighborhoods, including part of the Old City.

Lastly, the question of sovereignty over the Muslim 'AI Haram al Sharif' or Jewish 'Temple Mount'13 was a matter of passionate disagreement in Camp David as well as in Taba. The site is presently controlled by the Israel but overseen by theW aqf, a Muslim administrative body. Since the area represents the third holiest site in Islam, the Pal estinians wish to have complete sovereignty over it.

But according to the Israelis, the Dome of the Rock rests atop the remains of Judaism's holiest site, theancient Temple of Jerusalem. As a result, they believe they hold an equally valid claim to authority over the area. At Camp David, the A mericans suggested a system of horizontal borders: the Israelis would hold rights to the subsoil, and the Palestinians would enjoy rights over the surface. The latter rejected this proposal out of fear that the Israelis would engage in disruptive excavations under the Temple Mount. ${ }^{14}$ To complicate matters, there is another site of Moslem worship ${ }^{15}$ located under the Temple Mount, in the chambers known as Solomon's Stables.

While quite innovative, such proposals would be difficult to enact given the geographic realities. How is one to determine what is A rab and what is Jewish? Should property deeds be used as the point of reference, or should the population density of the areas in question?

\footnotetext{
13 Third holiest site in Islam, site of the Dome of the Rock and the AI-Aqsa Mosque. First holy site in Judaism, as the ancient Jew's Temple Mount.

${ }^{14}$ During the Taba talks, according to Miguel Moratinos (2001), the special reporter of the European Union: “both sides were close to accepting Clinton's ideas regarding Palestinian sovereignty over Haram al-Sharif, notwithstanding Palestinian and Israeli reservations", but no agreement was reached.

${ }^{15}$ Sidna Issa, "Jesus' Cradle".
} 
If the latter, the right of sovereignty over Jewish quarters of East Jerusalem would go to the Israelis and a modification of the international jurisdiction would be necessary. Finally, what status should be assigned to the $35 \%$ of municipal space still uninhabited. Should it be transferred to Israeli or Palestinian sovereignty?

\section{The idea of a sealed border in the xxist century}

Since the start of the AI-A qsa Intifada in 2000, support for the idea of unilaterally establishing a physical barrier between Israel and the $\mathrm{Pa}$ lestinian territories has grown tremendously among Israel is. Before the uprising began, most conservative and right-wing Israelis considered this position a form of retreaction, since it implies that Israel could no longer enforce its claim over the frontier areas of the West Bank. Support for the building of the security fence came from deputies such as Haïm Ramon on the left, and such moderates in the Likud Party as Dan Meridor. Gradually, however, a consensus grew that a sealed border would be effective in preventing terrorist attacks. In January 2000, A riel Sharon's government approved construction of a 440 $\mathrm{km}$ barrier between Israel and the West Bank. ${ }^{16}$ The government insisted that the barrier did not constitute a demarcation of Israel's national border: thelsraeli army would continue to enforce the security of zones $B$ and $C$, on the far side of the Green Line.

Settlers immediately opposed the plan, as they feared becoming isolated outside the barrier if at some later date it did, in fact, become the national border between Israel and a new Pal estinian state. When the subject of how the barrier might pass through Jerusalem first arose, several conservative ministers indicated their disapproval of any such plan, warning against any possible return to dividing the city. Though it soon became apparent that the barrier would not be built along the line of East and West Jerusalem but, instead, along

\footnotetext{
16 The government never said that the barrier would follow the Green Line, but that it should be settled approximately in the area of the Green Line.
} 
the municipal border, on the external fringe, some of these ministers were still adamantly opposed since they believed that such a barrier would impede the city's expansion beyond the limits of the municipality and so signal an end to the frontier days of Jewish settlement east of Jerusalem. The border would then be a closed one.

The Israeli government did not assert that the barrier's sole purpose was the prevention of terrorists incursions into Israeli territory. ${ }^{17}$ A policy of ethnic separation was clearly stated, the argument being that co-existence between Israelis and Palestinians had been a failure. The barrier was thus also seen as a solution to the demographic challenge of maintaining a Jewish majority in Jerusalem and, indeed all of Israel in the face of high Arab birthrates: demographic statistics indicated that Israel would lose its ethnic Jewish character if it continued to assert sovereignty over the West Bank and the Gaza Strip. In 1967, the ethnic distribution of Jerusalem's population was $74 \%$ Jewish, $26 \%$ Arab. Today it is 67\% Jewish and 33\% Arab (680,000 inhabitants). Between 1967 and 2002, the Jewish population grew 132\%, while the Arab population grew $223 \%$ over the same period. Projections for 2020 indicate a total population of 946,500 inhabitants, of whom 588,700 would be Jews, or $62 \%$ of the total population, and $38 \%$ non-Jews. ${ }^{18}$ Consequently, a barrier in Jerusalem was thus considered a tool for maintaining the Jewish majority there. That said, one can easily imagine a wave of legal or clandestine immigration by Palestinians living in nearby villages, villages sealed off by the barrier, as they can be expected to continue to seek a way inside in order to benefit from urban amenities found in East and West Jerusalem.

The Fence will have a disrupting effect on the lives of Palestinians in terms of spatial and social organization. East Jerusalem, with 223,000 inhabitants, is the second-largest city in Palestine (after Gaza). If we look at the overall population cluster of the region, we can see

${ }^{17}$ Since 1967 there have been 484 attacks in Jerusalem ( 492 killed, 2483 wounded). Since the beginning of the Second Intifada (in September 2000), there have been 127 attacks, or $22 \%$ (232 deaths) of the attacks in Israel for the same period.

${ }^{18}$ Source: Division for Strategic Planning and Research, Municipality of Jerusalem. 
that there is an urban continuity between Al-Bireh to the north and Bethlehem to the south. This cluster numbers 600,000 Palestinian inhabitants, nearly the same as the entire population of municipal Jerusalem (Israeli Jews and Arabs). Establishing the fence is a way of sectioning off this Palestinian urban continuity and hindering its development (Nasrallah, 2003).

Yet, for the first time, Israeli authorities are volunteering certain territories of Jerusalem as well. The Fenceroute del iberately excludes some Palestinian neighborhoods to the north which were subject to municipal jurisdiction: the Shu'afat camp, and parts of Bet-Hanina, Ar-Ram and Bir-N abala. Israel's government argues that these areas haveno historic or religious links to Jerusalem. The Pal estinians have pointed out that Israeli neighborhoods likeGilo, or Malchato the south, have no such links either. They also claim that the Pal estinian areas to the north have devel oped a strong functional connection with Jerusalem as the center of their population cluster, the chief job market for theregion, and thefocal point for higher level services such as schools, universities, hospitals, government offices, and transportation hubs. These neighborhoods represent the suburbs of East Jerusalem. The fence places heavy restraints on the daily life of Palestinians who live there or on theWest Bank but work in Jerusalem. The travel time between their homes and workplaces is greatly increased by the need to pass through the barrier's one and only checkpoint, where the waiting timecan beconsiderable. And to pass through this checkpoint, they must display a work permit which specifies where they will be traveling (Salter, 2005). It seems likely that Israeli authorities will reduce their quota on the number of permits issued to Palestinians from the West Bank.

With these northern neighborhoods excluded, the real perimeter of Jerusalem's municipal sovereignty will be reduced. At present, no official administrative changes have been announced, but it seems probablethat the Municipality of Jerusalem will no longer takecharge of the neighborhoods located beyond the security fence. Instead, they could pass under the jurisdiction of Ramallah district, which is contiguous. And well in advance of becoming a border between states, the fence will become the de facto municipal boundary of Jerusalem. 
This boundary will redefine the ethnic and national identity of Palestinians living on either side of the fence. Those in East Jerusalem will become Israelis, while those living beyond the pale will be excluded from Israeli citizenship and will be cut off from a part of their people (Klein, 2003). Families will be divided and social networks will no longer be maintainable between Israel and the West Bank. In light of such changes, will the inhabitants of East Jerusalem forge stronger bonds with Israeli Arabs, or will they try to maintain social and family relations on either side of the new concrete border?

The border's effect on the tourist industry will also be a handicap. Travelers from abroad will find it much more difficult to reach Palestinian territory. Sites like Bethlehem, Jericho, and the Dead Sea, once frequent destination points, will not see as many international or Israeli tourists as before. At the same time, Palestinian tourists will have trouble reaching sites in Jerusalem like the Holy City and other religious, historic or cultural sites of Arab and Muslim significance which are located in Israeli territory (Jaffa, Nazareth, A cre, etcetera). There is also a real likelihood that Jerusalem's international image will be tarnished by the construction of the security fence, a massive engineering project eight meters high in certain quarters of Jerusalem. However, the fence itself will be a new attraction for a specific kind of tourism, much as the Berlin Wall before 1989, which was a necessary stop point during the city's tour.

Will this barrier become the new border between Israel and Palestine? Official stances on both sides differ on what the consequences and significance of the Fence's construction will be. Israel's Ministry of Defense, which is responsible for building and supervising the barrier, states that it is not an international border but simply a security zone. ${ }^{19}$ It asserts that its route may bealtered in the future. It also claims that the barrier's construction is not necessarily an obstacle to Israeli-Palestinian peace negotiations nor to any debate over a future borderline between Israel and an eventual Palestinian state.

${ }^{19}$ A riel Shaul, Israeli Ministry of Defense reporter, in a Conference at Jerusalem Institute for Israel Studies, Jerusalem, December 31'st, 2003. 
The Ministry insists that the decision to build is one of basic selfdefense: it's argument, in essence, is one that echoes the words often heard in speeches by the Likud Party: "the architect of the Security Fence is not the State of Israel but Palestinian terrorism".

Palestinian authority disapproves of the construction of the fence and rejects any such action by Israel which has not been subject to negotiations between the two peoples. In Palestinian official discourse and media, the fence is referred to as "a barrier of division and apartheid". It is consider not only a border between nations but a massive obstacle designed to exclude them from one part of the region and confinethem to a restricted territory. Lastly, theroute of the fence is condemned extending the 1949 ceasefire line and leaving occupied Palestinian territories under Israeli control. ${ }^{20}$

Official voices in the international community appear to fall into two categories. The United States does not takea stand against the separation fence but criticizes the route chosen by Israel and recommends that it should follow the 1967 ceasefire line. Besides the U.S., those countries which have expressed an official position on the subject reject entirely the idea of walling off one people from another by means of a physical barrier. The United Nations General Assembly, for its part, has demanded an advisory opinion from the International Court of Justice in The Hague with regards to the Security Fence. The Court rendered its decision on July 9, 2004, stating that the barrier is contrary to international law and calling for its immediate dismantlement by Israel.

Although the barrier is not recognized as an official Israeli-Palestinian border, it will, in all likelihood, becomethebasic point of referencein future negotiations over the definition of an eventual borderline.

\section{Conclusion}

In July 2000, shortly before the beginning of the Second Intifada, during the Camp David conference, the negotiators addressed those subjects

20845,000 dunam (the Israeli dunam $=1000 \mathrm{~m}^{2}$ ), or $15 \%$ of the West Bank, according to an October 2004 report by B'tselem (The Israeli Center for Human Rights in the Occupied Territories). 
that had been marked as sensitive in the Declaration of Principles for the Oslo Accords in 1993. One of these was the future of Jerusalem, and it is not surprising that the positions of the two camps have become more entrenched at the very moment of reflection over areas judged to be so delicate. Defining the borders of Jerusalem is a susceptible matter for many reasons on many different levels.

It provokes the question of the possibility of peaceful coexistence between two peoples and among three religions. Do, or should, the internal and/ or external limits of thecity reflect a segregation of people along religious and ethnic lines?

Jerusalem al so involves a political and territorial problem for local governance. Defining the borders means defining the extent of local authority for I sraeli and Palestinian officials. Thenegotiators can conclude that two separate municipalities are needed, or they can prefer a single federal council.

Lastly, there is the problem of international jurisdiction, since theselimits may one day become borders between independent states. Then, each State will try to prove the legitimacy of its appropriation of a designated perimeter, using historical, religious or functional references, which will surely be partially contested by the second State. And both parties have staked strong claims to Jerusalem, at least to East Jerusalem, which is part of the occupied territories, according to international jurisdiction.

\section{Bibliography}

A ref AI A ref, 1961, TheParticulars of theH istory of Jerusalem, AI Ma'aref Printers, Jerusalem.

Ben Arieh Y., 1977, A City Reflected in its Times: Jerusalem in the $\mathrm{N}$ ineteenth Century, Yad Izhak Ben-Zvi Publications, Jerusalem.

Dieckhoff, A., 1989, Les espaces d'Israël, Presses de la Fondation Nationale des Sciences Politiques, Paris.

Dumper, M., 1997, The Politics of Jerusalem Since 1967, Columbia University Press, Institute for Palestine Studies Series, New York. 
Encel, F., 1997, Géopolitique de Jérusalem. Représentations, stratégies et perspectives autour d'unecitésanctifiée, Doctoral thesis, Paris VIIISaint-Denis University, Paris.

Hirsch, M. and Lapidoth R., 1994. Jerusalem: Political and Legal A spects (in Hebrew), Jerusalem Institute for Israel Studies, Jerusalem.

Klein, M., 2003., "Israel's Jerusalem Policy, Sparta and A partheid", B'tselem, November, Jerusalem.

Kodmani-Darwish, B., 1994, Perceptions de sécuritéet stratégies nationales au M oyen-O rient, IFRI research papers, Paris.

Legrain, J.F., 1996, “Judaïsation et démembrement: politiques israéliennes du territoire", M aghreb-M achrek number 152, A prilJune.

Moratinos, M., 2001, European Union Report on Taba Talks.

Nasrallah, R., 2003, "Jerusalem, the Geopolitical Settlement and the Israeli Imposed Physical Reality", in Khamaisi, R., N asrallah, R. and Younan, $M$., Jerusalem on the $M$ ap, International Peace and Cooperation Center, Jerusalem.

Neher-Bernheim, R., 1997, Jérusal em, trois millénaires d'histoire, Albin Michel, Paris.

N ewman, D. (ed.), 1999, Boundaries, Territory and Postmodernity, Frank Cass, Portland.

1985, Thel mpact of Gush Emunim: P olitics of Settlement in theW est Bank, Croom Helm, London.

Salter, M. B. 2005, “Israeli Biopolitics and the Documentation of Palestinian Closure", paper presented at Border Regions In Transition Conference VII, Van Leer Institute, January $8^{\text {th }}-12^{\text {th }}$, Jerusalem. Sharon, A. et al. 1973, Planning Jerusalem; the Old City and its Environs, Weidenfeld and Nicolson, Jerusalem.

Smotriez, Aurelia, 1998, Lemotif dela frontière; au miroir dela littérature israélienne, ENS deFontenay-Saint-Cloud and Paris VIII-University, Paris. 
